\title{
A Review on: The Importance, Distribution and Threat of Ethiopian Wetlands
}

\author{
Feto Haji \\ College of Natural and computational science Department of Biology Madda Walabu University, \\ PO-box 247,Bale Robe, Ethiopia
}

\begin{abstract}
Ethiopia, like as many countries in the world, has immense wetland resources. The wetlands in Ethiopia include many forms such as lakes, swamps, marshy wetlands, peat wetlands, flood plains, high mountain lakes, natural and manmade ponds. These wetlands have been contributing for the well-being of many Ethiopians for generations and still they are contributing and this will continue for years in the future. Wetlands, according to the Ramsar Convention are defined as "areas of marsh, fen, peat land or water as, whether natural or artificial, permanent or temporary, with water that is static or flowing, fresh, brackish, or salt including areas of marine water, the depth of which at low tide does not exceed six meters". In Ethiopia there are large areas of wetlands which are distributed in various parts of the country almost all altitudinal ranges from lowland (the Dallol depression) up to top of high mountains. Wetlands are of enormous socioeconomic and environmental values and attract a number of users that get benefited directly or indirectly. They are source of water, food, reed, medicinal plants and other income generating activities for the rural community.Wetlands generally classified into 3 major classes: freshwater, saltwater and manmade wetlands According to the FAO in 1984, two types of wetlands (swamps and marshes) dominate in Ethiopia and some studies show that based on scattered information, wetlands are estimated to cover about $2 \%$ of the total land mass of the country. Though wetlands in the country is poorly studied and recorded more than 40 wetlands are identified as important bird areas for the nation, and these sites support some of the endemic bird life and biodiversity of Ethiopia. The main objective of this paper is to discuss the importance, distribution and threats to wetlands of Ethiopia.
\end{abstract}

Keywords: Wetland, Ramsar convention, wetland management, threat

DOI: $10.7176 / \mathrm{JNSR} / 9-6-02$

Publication date:March $31^{\text {st }} 2019$

\section{Introduction}

Wetlands have been intricately linked with humankind throughout the ages. Evidence of rice culture dates to the earliest age of humans, long before the era of historical records About $40 \%$ of the world's population uses rice as a major staple; rice culture currently occupies about $15 \%$ of the world's wetland area. Wetlands are valued for high biological productivity; as filters, sinks, and transformers for sediments, nutrients, and pollutants; and as buffers between aquatic systems and human activities on upland areas (Donald, 1993).

Wetland ecosystems as suggested by Jos et al., 2006 are a natural resource of global significance and historically, their high level of plant and animal (especially birds) diversity is perhaps the major reason why wetland protection has become a high priority. Various Authors have defined wetlands differently. However as per the Ramsar Convention (1971) wetlands are defined as 'Areas of marsh, fen, peat land, water whether natural or artificial, permanent or temporary, static or flowing, fresh, brackish or salt and including areas of marine water the depth of which at low tide does not exceed six meters'.

According to Fish and Wildlife service (US), Wetlands are "lands transitional between a terrestrial and aquatic system where the water table is usually at or near the surface of the land or the land is covered by shallow water" (Cowardin et al., 1979).

Ethiopia is a country in the horn of Africa with an estimated area of around 1.1 million $\mathrm{km}^{2}$.It is often referred as the Water Tower of Africa. Around $70,000 \mathrm{~km}^{2}$ areas are covered with natural inland water bodies including rivers, lakes and associated wetlands (Ayenew, 2009).

In Ethiopia these resources are distributed in almost all altitudinal ranges from the Dallol depression up to top of high mountains. However, Shewaye (2008) suggested that, their exact area coverage is not clearly known for two vital reasons. The first one is that they are not studied in detail and the second reason is their changing in size in both in dry and wet seasons (expand in wet season and shrink in dry season). However, some assessments estimate that they may cover about $2 \%$ of the land.

As per the Ramsar definition, there are different types of wetlands in Ethiopia. These include among others: lakes, swamps, flood plain, natural or artificial ponds, etc. The formation of which is the result of tectonic movements, a continuous process of erosion and human activities.

As FEPA's 2003, described that, the Ethiopian wetlands render social, economic and ecological benefits. These benefits include: the provision of food, water, furniture, dry season grazing for cattle, regulation of hydrological systems, flood control, filtration of water flow and sediment trapping, reeds for thatching, crafts or 
floor covering, provision of medicinal plants, fishery resources, permanent source for irrigation, recreation and tourist areas, phytoplankton and zooplanktons organisms as useful sources of nutrient products, cultural and ethical values, etc.

According to EFAP (1989), Ethiopia, with its different geological formations and climatic conditions is endowed with considerable water resources. Wetland ecosystems, including twelve river basins, eight major lakes, many swamps, floodplains and man-made reservoirs and about 110 billion cubic meters of water runs off annually from the above sources (Leykun, 2003 \& Finlayson et al., 1999).

\section{Literature Review}

\subsection{Importance of Wetlands}

Wetlands provide multiple ecosystem services such as storing and regulating water flows and water quality, providing unique habitats to flora and fauna, and regulating micro-climatic conditions (Teferi et al., 2010).

As shown in (Illueca and Rast, 1996), Freshwater resources are a finite, but global consumption rates are known to increase from 2-3\% every year and Africa uses only 4\% of its renewable freshwater resources because of the uneven distribution of water resources over the continent, At the same time, (UNEP, 2006) describe that, access to water is affected by its quality and much of Africa's water may be unsuitable for consumption by its people. These regional patterns are also evident in Ethiopia, where water resources are unevenly distributed and only a quarter of its population has access to safe water and sanitation.

Wetlands are said to perform "hydrological functions" to "act like a sponge ", soaking up water during wet periods and releasing it during dry periods. (Bucher et al., 1993), reports there for wetland conservation is made in terms of ecosystem functioning, which result in a wide range of values including ground water recharge and discharge, sediment stabilization and water quality.

According to Nyman (2011), the wetland function includes the following details:

Flood conveyance: Wetlands associated with rivers and floodplain often form natural floodways that convey floodwater from upstream to downstream sites.

Protection from storm waves and erosion: Coastal wetlands and inland wetlands located adjacent to large lakes and rivers reduce the impact of storm tides and waves before they reach the uplands.

Sediment control: Wetlands filter sediment from floodwaters; this function can become saturated.

Habitat for fish and shellfish: Wetlands are essential spawning and nursery habitat that support commercial and personal fish and shellfish harvesting for human and animal food, especially in coastal waters, as well as for rare and endangered fish and shellfish.

Habitat for water birds and other wildlife: Coastal and inland wetlands provide essential breeding, nesting, migratory, and non-breeding habitat for numerous species of waterfowl, wading birds, shorebirds, mammals, reptiles, and amphibians; some of these species are robust enough to support hunting whereas others are rare and endangered.

Recreation: Wetlands are the sites for fishing, hunting, and non-consumptive use of wildlife and fish.

Source of water supply: Wetlands are important in the transmission and quality of ground and surface water.

Timber production: Under the proper management, forested wetlands are an important source of timber, but additional care will be needed in coastal wetland forests because of subsidence and/or sea-level rise.

Preservation of historic and archaeological values: Some wetlands are of archeological interest, particularly those located near Native American settlements.

Education and research: Wetlands provide significant educational opportunities for nature observation and scientific study.

Open space and aesthetic value: Coastal and inland wetlands are areas of great diversity and beauty that provide open space for recreation and visual enjoyment Water quality improvement: Wetlands contribute to improving water quality by removing excess nutrients and many chemical contaminants.

\subsection{Wetlands in Ethiopia}

As per Abebe (2008), Ethiopia is a country in North-Eastern Africa lying between $8^{\circ} 00^{\prime} \mathrm{N}$ and $38^{\circ} 00^{\prime}$ E. Its area covers an estimated $1,127,000 \mathrm{~km}^{2}$ of which some $7,444 \mathrm{~km}^{2}$ is covered by water. Ethiopia has $5,311 \mathrm{~km}$ of frontiers (line between two countries) that it shares with Djibouti, Eritrea, Kenya, Somalia and Sudan. Detailed inventory of the wetland resource base of Ethiopia is not carried out yet. However, based on scattered information, wetlands are estimated to cover about $2 \%$ of the total land mass of the country. The wetlands are distributed across all agro-ecological zones of the country from high altitude alpine lakes to lowland wetlands. Except coastal wetlands, all the other wetland types are found in Ethiopia which consists of flood plains, lakes, swamps/marshes, swamp forests and human made wetlands. The widely recognized wetland types are however, swamps and marshes, which together account for about $0.16 \%$ of the country's total area (EPA, 2004).

The major flood plains of Ethiopia as implied by various authors (Hughes and Hughes, 1992; EPA, 2004), include Wabeshebele-Genale flood plains, Awash River flood plains, Omo River flood plain, the permanent 
swamps and flood plains along Akobo, Baro and Gilo Rivers, Fogera and Dembia flood plains on the shores of Lake Tana, Borkena and Cheffa flood plains are few to mention. Lakes are the widely distributed types of wetlands in Ethiopia both on highlands and lowland parts of the country with the largest concentration in the great East African Rift valley system (EPA, 2004). The freshwater marshes and swamps as Leykun, 2003 described that, is dominantly found at the valley bottom, widely distributed in South-west highlands of Ethiopia at the head water of Baro-Akobo, Omo and Blue Nile rivers. Swamp forests are small in extent mostly found along Baro river depression in western Ethiopia. Human made wetlands include artificial impoundments, hydropower dams and municipal water supply reservoirs (Hughes and Hughes, 1992).

\subsection{Roles of Wetlands in Food Security in Ethiopia}

According to Legesse (2008), the concept of food security is built on three pillars: availability (sufficient quantities of food available on a consistent basis), access (having sufficient resources to obtain appropriate foods for a nutritious diet) and use (appropriate use based on knowledge of basic nutrition and care, as well as adequate water and sanitation) Therefore, food security according to FAO, 2003) is defined as "a situation that exists when all people at all times, have physical, social and economic access to sufficient, safe and nutritious food which meets their dietary needs and food preferences for an active and healthy life".

\subsubsection{Agriculture}

The needs of agriculture for flat topography, fertile soil and reliable supply of water mean that wetlands are often potentially valuable agricultural resources (McCartney et al, 2005).In many parts of Ethiopia, where valley bottom swamps and seasonal flood plains are found, agriculture is one of the economic pursuits among farming communities with a range of crops such as maize, vegetables, root crops and rice, being cultivated. Indigenous farming has been developed especially during dry season after the water receded, e.g. "bonnie" agriculture in western zones of Oromia and "Bahir shesh" on the shores of Lake Tana, Amhara. Wetland agriculture is the key component of food security strategies of the local communities (Bognetteau et al., 2003).

It has been implied by Legesse, 2007 that, currently, wetland cultivation in the area increased to the extent of complete cultivation of all the available wetlands in some localities. For instance, in Illu-Abba-Bora Zone, the percentage of the available wetlands under agriculture increased by more than double (from $27.7 \%$ in 2003 to $65.6 \%$ in 2006).

\section{Livestock Production}

Community groups who depend on livestock production for their livelihood directly get benefits from wetland grazing. For instance, Borkena and Cheffa wetlands support thousands of pastoralists from nearby Afar, Amhara and Oromia Highlands who move to the wetlands with their livestock during dry seasons in search of pasture and water. Wetlands, through provision of pasture and fodder play considerable role in the livestock production sector (Legesse, 2008).

\subsubsection{Water Supply}

Wetlands provide many communities with a direct source of water for human and animal consumption, agriculture and industry (Legesse, 2007).

\subsubsection{Harvesting Natural Products}

Wetlands are the most productive ecosystems which supply wide diversity of natural products directly consumed or marketed for income generation. Depending upon the type of wetland, many products can be harvested from wetlands, and are often the most direct economic benefits. The list of the products include: sedge, fuel and construction wood, medicinal plants, edible plants, craft materials and ornamental plants .Sedge harvested from wetlands are used for various purposes such as roof thatching (dwelling house, pest watching tukul, granary (grain storage) livestock shelter), beehive covering, as raw material for crafting (raincoat, matt, broom, basket, boat, carpet etc), ceremonial (floor covering during festivals), for mulching in nursery, compost making and fodder (Afework et al., 2000).

\subsubsection{Fishery}

Fish is another important product of wetlands which provide both as domestic protein source and for income generation for many families in Ethiopia as in many countries around the globe. Wetlands are important breeding, nursery and feeding grounds for fish. Some fish stocks remain within the wetland, others move away as adults. Therefore, wetlands are a major source of fish and wetland fisheries constitute a very important sector of the local economy especially in the Rift Valley areas of Oromia and SNNPR and around Lake Tana in the Amhara Region (Lemlem, 2003).

\subsubsection{Tourism}

Wetlands have unique landscape with great scenic beauty in addition to endowment with rich plant and animal diversity. Therefore, wetlands are one of the natural attractions for promotion of nature oriented tourism (ecotourism) such as bird watching, boating, sport fishing. Community based ecotourism is one way of improving and diversifying the income of local communities, and thereby contributes towards food security and poverty reduction. The local people benefit as tourist guide, sale their products to visitors and employment opportunities in tourist 
service facilities like hotels and resorts. The rift valley lakes (Ziway, Abiyata, Shalla, Langanno, Awasa and Abaya), creator lakes (Bishoftu, Wenchi), Tana, Ashenge, salt marshes and lakes in the Afar depression, the alpine lakes of Bale Mountains are some of Ethiopian wetlands that have great tourism potential (EWNRA, 2005; Legesse, 2008).

Some of the ecological functions that the Ethiopian wetlands have included: The Rift Valley lakes and wetlands support thousands of birds; serve as stop-over sites for migratory species including those worldwide endangered bird species. An example is the large number of lesser flamingos $(230,000)$ reported between 1990 and 1994 in Lake Abijata (Siraj, 2004). Afework, 2005 describe that, overall, more than 40 wetlands are identified as important for wetland birds areas within the country as a whole; that support a variety of bird species including some endemic bird forms.

\section{Wetland Distribution in Ethiopia}

As implied by Afework, 2005, Wetlands are distributed throughout the world from the polar region to the tropics, from highlands to lowlands and they account nearly for $6.4 \%$ of our world. However, their distribution is not uniform from one country to another, even within a country it varies from region to region. As a case there are more wetlands in Ethiopian rift valley than in the eastern part of the country. In Ethiopia there are quite large areas of wetlands in various parts of the country from lowland to highlands. According to the FAO land use map of the country made in 1984, two types of wetlands dominated in Ethiopia.

Swamps: which are permanently flooded areas with herbaceous vegetation (usually greater than one meter in height). Swamps are dominated by trees or shrubs and occur in a variety of flooding conditions. Standing water can be present in swamps during all or just a small part of the year. Water chemistry in swamps can vary greatly, depending on the water source.

Marshes: which are also permanently flooded areas with herbaceous vegetation (usually less than one meter). Or marshes are periodically or continually flooded wetlands characterized by non woody emergent plants, plants that are adapted to living in shallow water or in moisture-saturated soils. On the other hand, Hillman (1993) listed more than 44 wetlands with a total area of $13,699 \mathrm{~km}^{2}$ of the country's land surface. However, other estimates with additional evidences from various sources estimate the total wetland area of Ethiopia at $22,500 \mathrm{~km}^{2}$, some $2 \%$ of the country's land surface.

Wetlands are widely distributed in all climatic regions of Ethiopia and support a wealth of flora and fauna, including many endemic plant species and several of Ethiopia's endemic birds. Some birds, for example, Spotbreasted Plover, Blue-winged Goose, Rouget's Rail, White-winged Fluff tail, Wattled Crane, Corn Crake, Shoebill, Black-winged Pratincole, Great Snipe, and Lesser Flamingo in general favor, feed and or breed in this wetlands (Mengistu, 2008).

\subsection{Classification and Locations of Ethiopian Wetland}

A simplified classification provided by the Ramsar Convention categorizes wetlands into 3 major classes: Fresh water wetlands, Salt- water wetlands and Man-made wetlands (Afework, 2005).

\section{Fresh water wetland}

Riverine -Permanent Rivers and streams

Lacustrine -Permanent freshwater lakes

Palustrine -Permanent freshwater marshes \& swamps

\section{Salt water wetland}

Marine -Sub tidal unvegetated shallow waters

Estuarine -Sub tidal estuarine

Lagoonar: brackish to saline lagoons.

Salt lake: brackish, saline or alkaline lakes

\section{Man-made/human wetlands}

Aquaculture/mariculture - aquaculture ponds

Water-storage areas

According to Leykun, 2003, at the macro level, wetlands may be classified according to biomes. At the local and more specific level, wetlands may be grouped according to their habitat type, physical and biological characteristics. Ethiopian wetlands can be grouped into four major categories based on ecological zones, hydrological functions, geomorphologic formations and climatic conditions. These categories interlink to form four major biomes, which also describe climatic conditions in Ethiopia. These biomes are the Afro-tropical highlands, the Somali- Masai, the Sudan-Guinea and the Sahelian transition zone groups.

\section{Group I - The Afro-tropical highland system}

The Afro-tropical highlands are composed of the Central, Western and Eastern highlands of Ethiopia that serve as the prime water catchments and sources of its major rivers. The average annual rainfall is more than 2,000 $\mathrm{mm}$. 
Rains are bimodal, with the long rains extending from June to September and short rains between February and May (Tilahun et al., 1996).

These areas include most of Ethiopia's alpine and fresh water wetland ecosystems. The wetlands in this biome include Lakes Tana, Hayk, Ashange, Wonchi and, in the Western Highlands, Gojjeb and Ghibe. Floodplains associated with the biome's lakes and rivers are the Fogera and Dembia on the shores of Lake Tana. Some of the important wetlands of the Central Highlands are the Chomoga-Yeda floodplains around Debre Markos, and the Borkena and Dillu swamps in the Upper Awash Basin. The numerous alpine lakes of the Bale Mountains and the swamps of Arsi and Alemaya are important wetlands in the Eastern Highlands (Leykun, 2003).

\section{Group II - Somali-Masai wetland system}

This biome also exists, in large measure, due to the formation of the Great Rift Valley. Its wetlands include the southern group of the Great Rift Valley Lakes and the northern group of the Awash Basin together with their associated swamps and marshlands. The water-divide of these two wetland complexes is near Meki town. The Awash Basin wetland complex is to the north of the water divide and includes the wetlands of Bishoftu, the KesemMeteka complex and Lake Abe complex. The southern group comprises three separate and closed drainage systems. The first system comprises lakes Langano, Abijatta and Shalla. The second drainage system comprises Lake Awassa and Chelekleka, while the third comprises the rivers Abaya, Chamo and Chew Bahir together with their associated floodplains. The rainfall distribution under this biome is bimodal, with peaks between September and November, and March and May (Tilahun et al., 1996).

\section{Group III - Sudano-Guinean wetland system}

The Sudano-Guinean wetland system is found in the western lowlands of Ethiopia. The wetlands in this group stretch from the Turkana delta in the south-west of Ethiopia, north along the Ethio-Sudanese border, the BaroAkobo flood plains in Gambella Region, the Dabus and Beles floodplains in the Benshangul-Gumuz Region and the Metema and Tekeze flood plains in Amhara and Tigray Regions. Rainfall is uni-modal, from March to September (Leykun, 2003).

\section{Group IV - Sahelian transitional wetland system}

The Sahelian transitional zone biome is that found in the extreme north-eastern part of Ethiopia. This area is the hottest and driest part of the country and is where the Dallol depression is located - at its lowest point; Dallol is $116 \mathrm{~m}$ below sea level, the biome contains a number of fresh and saline wetlands, including Lakes Afambo, Afdera, Gamari and Asali.

The water volume of these lakes is dependent on the rainfall from the highlands during the wet season. In the dry season, most of the water in these wetlands evaporates leaving large salt pans behind. Rainfall is uni-modal and unreliable, with a small amount received mainly between November and February (Tilahun et al., 1996).

\subsection{Major Wetland Types and their Distribution Across the Country}

Ethiopia has various types of wetlands that vary in size type and location. The types of wetlands that are found and dominate in one area might be found rarely in other parts of the country. As an example valley bottom wetlands such as marsh and swampy wetlands, dominate the South-western Ethiopia, whilst lakes and lake associated wetlands are dominant within the Rift Valley. In some parts of the country, like the western lowlands, floodplain types of wetlands are dominant.

For convenience propose the major types of wetlands that are found within the country are summarized as follows based on information collated from different sources (Leykun, 2003; Afework, 1998 and FAO, 1984). The list provided here is not exhaustive by any means and numerous wetlands that exist all over the country are not mentioned. It is only the major types of wetlands that are tried to be listed here.

\section{Lake Tana and associated wetlands}

Lake Tana

Fogera Floodplain

Dembia Floodplain

Dangela and the surrounding Wetlands

The Ashenga and Hyake Lakes

Wetlands of the Bale highlands

Numerous alpine lakes including Gerba Gurecha

Swamps and floodplains

Wetlands of the western highlands

Keffa, Bench Maji and Sheka including Ghibe and Gojeb Floodplains

Illubabor, Jimma and Wollega valley bottom wetlands, dominated by marsh and swamps

\section{Lakes of Bisoftu}

Creater lakes - Hora, Bishoftu Guda and Zukala

Grean, Babogaya and Bishoftu Lakes etc. 
Lakes and associated wetlands of the southwest rift valley

Lakes Ziway, Langano, Abjiyata, Shalla

Lake Awassa and Chelekleka Wetland system

Lakes Abaya, Chamo, Chew Bahir

Lake Turkana

Lakes and swamps of the Awash river system

The Upper Awash Valley - Dillu Meda, Aba Samuel

The Lake Beda sector

The Gewane Lakes/Swamp Complex

The Dubti, Afambo and Gemari Lakes/Swamp complex

Lake Abe and delta

Lakes of the Afar depression

Lake Afera

Lake Asale

Dallol Depression

Western river floodplains

Alwero, Baro, Akobo, Gilo

Chomen, Fincha Swamps

Dabus Swamp

Beles Floodplain

Lake Alemaya and associated wetlands

\section{Threat to Wetlands of Ethiopia}

While wetlands may be the most productive of ecosystems on earth, they are also the most threatened. Wetland destruction and alteration has been and is still seen as an advanced mode of development, even at the government level. Wetlands and their value remain little understood and their loss is increasingly becoming an environmental disaster. While rates of wetland loss are documented for the developed world, the limited study of these ecosystems in countries like Ethiopia leaves us with little to say (Abebe, 2003).

Humans usually and very dramatically accelerate natural processes often unintentionally but usually in the course of activities like agriculture, industry and urban development. These activities can involve anything from drainage and diverting water, to dredging and loading water sources with toxic chemicals. Perhaps the most destructive of all activities is mining which permanently destroys the substrate and prevents the natural restoration of a site. Wetlands whose biotic balance has been disturbed can often recover (Williams, 1990).

Dugan (1990) claims that $65 \%$ of wetland disturbances are of human origin, while the remainder have natural origins. Out of these, $73 \%$ of disturbances are thought to result from direct human actions, while the remaining $27 \%$ are believed to come from indirect sources (Table. 1 ).

Table 1. Causes of wetland loss: source from (Abebe, 2003).

\begin{tabular}{|l|l|l|}
\hline \multicolumn{2}{|c|}{ Human action } & \multirow{2}{*}{ Natural causes } \\
\hline Drainage & Indirect & Subsidence \\
\hline Dredging & Sediment diversion & Drought \\
\hline Filling & Hydrological alteration & Hurricane and storm \\
\hline Conversion & Subsidence(sink into ground) & Erosion \\
\hline Construction & & Biotic effect etc. \\
\hline Discharge & & \\
\hline Mining & & \\
\hline Abstraction & & \\
\hline
\end{tabular}

One cannot exhaustively list the threats of that Ethiopian wetlands are confronting at present, since the type of threats varies from one place to the other and due to the existence of a variety uses of wetlands within the country. According to Afework, 2005, some of the threat to wetland in Ethiopia includes:

A. Lack of awareness, information and research work on wetlands -Lack of awareness within the general public, policy and decision makers within the country has impacted on the use and conservation of wetlands within the country. Little information is available for the general public due to limited research work on wetland resources.

B. Draining wetlands for agriculture use -Draining of wetlands for agricultural purpose is a century-old practice in some parts of the country, mainly in Southwest Ethiopia. However, improper draining mechanisms, double cropping, growing of perennial crops such as sugarcane within wetlands ecosystem has become a major threat for the survival of wetlands. Long-term draining interferes with the ecological recovery of the 
wetland system and will speed up the drying up of the wetland.

C. Grazing in wetlands- Throughout Ethiopia wetlands have been, and still are, important sites for livestock grazing. Wetlands are the last destination for grazers during the dry months in the country from North to South and East to West. It might not be overestimating to say that the survival of the country's livestock is unthinkable without the existence of these precious resources.

D. Over exploitation of wetland resources- Wetlands have diverse resources that have immense values for the human resources. Many citizens are dependent on these resources for their livelihoods. Out of the many resources that wetlands provide for humans, the most important resources like fishes, reeds, water, medicinal plants and food and fodder to their cattle. However, the use of these resources is not often based on a studied assessment and their sustainability is under a serious threat. Over-exploitation of these resources is a major threat for their survival

E. Deforestation, siltation, soil erosion and land degradation- Deforestation within a wetland catchment will be a starting point for an accumulation of silt within a wetland ecosystem. Loss of vegetation within the catchment will result in accelerated soil erosion and consequently lead to land degradation which in general is a major cause for an accumulation of silt within the wetland which leads to a complete change in the wetland ecosystem.

F. Urbanization, settlement, pollution from urban centers and industrialization - Due to the attractive nature and abundance of natural resources in wetlands many urban centers around the globe, including Ethiopia, are located near or adjacent to wetlands. Good examples within Ethiopia are which are located near lakes, whilst Gimbi town is also located near an extensive swamp wetland. However, through time the presence of these urban centers or settlements has become a source of threats through pollution to the resources.

As described by Afework 2005, other major threats to wetlands include:

-Introduction of perennial crops into wetland ecosystem such as Eucalyptus,

-Planting of high water demanding plants into the wetland ecosystem such as Sugarcane,

-Appearance of invasive plants species within the wetland,

-Government policy that encourages draining wetlands to meet the country's food shortage,

-Introduction of alien plant species into wetland ecosystems.

\subsection{Threat and Cause of Wetland Loss in Ethiopia}

Conversion of wetlands for agricultural use is a widespread practice in Ethiopia, particularly in the southwestern part where wetlands cover large areas (Teferi et al., 2010).

According to a study conducted by WCED', in 1987 showed that, the causes of wetland degradation include the conversion of wetlands for intensive irrigation agriculture, the expansion of human settlement, industrial pollution, pesticides and fertilizers and water diversion for drainage and the construction of dams.

Wetland loss is evident wherever major developments like dams, irrigation schemes and conversion projects are present in the developing world.

(Barbier et al., 1996) suggest that, most of the threats that wetlands face result from their misuse and many are also related to unsustainable resource extraction. Another important reason for their vulnerability is the fact that they are dynamic systems undergoing continual changes as a result; many wetlands are showing temporary features that disappear, reappear and re-create themselves over time. Alan and Adrain,(2007) state that, wetlands are becoming increasingly recognized as important natural resources in developing countries because of their ability to fulfill a range of environmental functions and produce a number of products that are socially and economically beneficial to local communities.

Wetlands act as sponges during dry periods of the year; they regulate run-off and recharge groundwater resources, and they purify water supplies. Their capacity to store water means they are able to support livelihood strategies, such as fishing, pastoralism and agriculture, as well as providing craft materials, clean drinking water and medicinal plants (Dugan, 1990 and Silvius et al., 2000).

According to Desta \& Mengistu, (2008) Ethiopia having variable topography and altitudinal range, from $126 \mathrm{~m}$ below sea level to 4,620m above sea level (a.s.1.), is a country endowed with rich wetland resources that include lakes, marshes, and swamps. According to (FAO, 1984), swamps and marshes are the two dominant wetland types, especially in southwestern part of the country.

Ethiopia, with its different geological formations and climatic conditions, is endowed with considerable water resources and wetland ecosystems, including twelve river basins, eight major lakes, many swamps, floodplains and man-made reservoirs. Ethiopian wetlands are currently being lost or altered by unregulated over-utilization, including water diversion for agricultural intensification, urbanization, dam construction, pollution and other anthropogenic interventions (Leykun, 2003). 


\section{The Ramsar Convention}

The Convention on Wetlands is an intergovernmental treaty adopted on 2 February 1971 in the Iranian city of Ramsar, on the southern shore of the Caspian Sea. Thus, though nowadays the name of the Convention is usually written "Convention on Wetlands (Ramsar, Iran, 1971)", it has come to be known popularly as the "Ramsar Convention". Ramsar is the first of the modern global intergovernmental treaties on the conservation and sustainable use of natural resources (Abebu, 2008).

\subsection{Criteria for the Identification of Wetlands as Ramsar Site}

Guidelines for the selection of Ramsar Sites have been adopted by the $4^{\text {th }}$ and $6^{\text {th }}$ Conference of the Parties (COPs) Meetings to assist the realization of Article 2.1 and the criteria for the selection of wetlands as Ramsar Site are depicted here under: (Ramsar Convention Manual $4^{\text {th }}$ ed.).

Criteria1: A wetland should be considered internationally important if it contains a representative, rare or unique example of a natural or near natural wetland type found within the appropriate bio-geographical region.

Criteria 2: A wetland should be considered internationally important if it supports vulnerable, endangered, or critically endangered species or threatened ecological communities.

A wetland should be considered internationally important if it:

Criteria 3: A wetland should be considered internationally important if it supports populations of plant or animal species important for maintaining the biological diversity of particular bio- geographical areas.

Criteria 4: A wetland should be considered internationally important if it supports plant or species in critical stage in their life cycles, or provides refuge during adverse conditions.

Criteria 5: A wetland should be considered internationally important if it regularly supports 20,000 or more water birds.

Criteria 6: A wetland should be considered internationally important if it regularly supports $1 \%$ of the individuals in a population of one species or sub species of water bird.

Criteria 7: A wetland should be considered internationally important if it supports a significant proportion of indigenous fish sub species, species or families, life history stages, species interactions and benefits and/or values and thereby contributes to global biological diversity.

Criteria 8: A wetland should be considered internationally important if it is an important source of food for fishes, spawning ground, nursery and/or migration path, on which fish stocks either within the wetland or elsewhere depend.

\section{Ramsar convention in Ethiopia and current status of ratifying the Ramsar Convention}

Ethiopia has participated in Ramsar Regional and COP Meetings as observer and maintains good communication with the Ramsar Bureau. Using the financial support from the Ramsar Bureau, the Federal Environmental Protection Authority (FEPA) has organized Accession Workshop which took place on March 18-19, 2004 in Addis Ababa. Key governmental and nongovernmental organizations working in the Federal and Regional States have participated on the National Consultative Workshop (FEPA, 2004). As per the Proceedings of the workshop, consensus has been reached that the Ethiopian Government should ratify the Ramsar Convention and in line with the convention's requirement a National Committee was formed to identify the first Ethiopian Ramsar site. Accordingly, the National Committee selected Abijata-Shalla as the first Ethiopian Ramsar Site (Abebu, 2008).

The FEPA to push the ratification process forward has coordinated the preparation of site map and Ramsar sheet for the first Ethiopian Ramsar site using the financial and technical supports obtained from IUCN. The same organization has also provided financial support for the preparation of management plans of Abaya-Chamo and Cheffa wetlands which are likely to be potential Ramsar sites.

Aware of the ecological, economic and social values of wetlands, many countries signed the international agreement on wetlands in 1971 in Ramsar, Iran, commonly known as the Ramsar Convention. According to Abebu, 2008, Ethiopia having various types of wetlands with national and international significances but the country has not yet ratified the Ramsar Convention.

\section{Conclusion}

The present studies show that, the Ethiopian wetlands are distributed in different parts of the country, in almost all ecological and altitudinal ranges covering approximately $2 \%$ of its total surface area. The country lacks wetland database as comprehensive wetland study has not been carried out yet. The existing estimations of its extent are based on some general environmental assessments. Wetlands have diverse benefits and their sustainable use should be maintained. To ensure this, environmental impact considerations during the formulation and implementation of wetland-related policies, programmes, plans, strategies and projects should receive the utmost attention.

Wetlands are distribute in various parts of the country from lowland to highlands Their distribution is not uniform \& varies from region to region Lakes are the widely distributed types of wetlands. Though wetlands in the country is poorly studied and recorded More than 40 wetlands are identified. Wetlands of Ethiopia are of enormous 
ecological and socioeconomic significance. However, they are losing their vigor at an alarming rate due to unwise management. Local Communities are the immediate beneficiaries of wetlands and are also first level victims of wetland loss. The participation of local communities in wetland management is of paramount importance.

\section{References}

Ababu, A., 2008. Ramsar Convention in Ethiopia, Current Status and Future Perspectives. Role of Federal Environmental Protection Authority in Ratifying the Ramsar Convention and Wetland Policy Development. pp.52-58.

Abebe, Y., 2003. Wetlands of Ethiopia. An introduction in proceeding of a seminar on the resources and status of Ethiopia's wetlands. IUCN- The World Conservation Union Nairobi, Kenya, pp.1-11 .

Afework, H., 1998. An overview of wetland use in Illubabor Zone, South-western Ethiopia, EWRP, Metu, pp.2123.

Afework, H., 2005. Ethiopian Wetlands Distribution, Benefits and Threats. Proceedings of the second awareness creation workshop on Wetlands in the Amhara region, Addis Ababa Ethiopia, pp. 9-16.

Afework, H., Dixon, A.B. and Wood, A.P., 2000. Nature, extent and trends in wetland drainage and use in Illubabor Zone, Southwest Ethiopia. Ethiopian Wetlands Research Programme and the University of Hudders field, pp.117-129.

Alan, B., Dixon and Adrain, P.,W., 2007. Local institutions for Wetland Management in Ethiopia: Sustainability and State intervention, $\mathrm{CAB}$ International. Community-based water law and water resource management, In: Van Koppen, M. Giordano and Butterworth, J (Eds),pp.130-132.

Ayenew, T., 2009. Natural Lakes of Ethiopia. Addis Ababa University press, Addis Ababa. 206pp.

Barbier, E. B., Acreman, M. C. and Knowler, D., 1997. Economic valuation of wetlands: A guide for policy makers and planners, Ramsar Convention Bureau,pp.127-129.

Bognetteau, E., Wood, A.P., Afework, H. and Legesse, T., 2003. Wetlands and Food Security in South-west Ethiopia: An Economic, Ecological and institutional analysis for sustainability. EWNRA, Addis Ababa, pp. 6-7.

Cowardin, L.M., .Carter, V.F., Golet, C. and Larose, E.T., 1979. Classification of Wetlands and Deepwater Habitats of the United States, Washington D.C.: U.S. Fish and Wildlife Services, U.S. Department of the interior, pp.131-132.

Desta, H.Y. and Mengistu, S., 2009. Water quality parameters and macro invertebrates index of biotic integrity of the Jimma Wetlands, Southwestern Ethiopia: Wetland Friends of Nepal, Journal of Wetlands Ecology, 3:7793.

Donald, H.,1993. Wetlands: history, current status, and future, Environmental toxicology and chemistry. 12 (12): 57-66.

Dugan, P. J., 1990. Wetland Conservation: A review of current issues and required action. IUCN, Gland, Switzerland, 94pp.

EPA, 2003. State of the Environment Report for Ethiopia. Environmental Protection Authority (EPA), Addis Ababa, Ethiopia.pp31-32.

EPA, 2004. Proceedings of the National Consultative Workshop on the Ramsar Convention and Ethiopia: Federal Environmental Protection Authority (EPA), Addis Ababa, Ethiopia, pp29-31.

EWNRA, 2005. Proceedings of the Second Awareness Creation Workshop on Wetlands in the Amhara Region,pp.4-7.

FAO, 1984. Assistance to Land use, Ethiopia, A land resources inventory for land use planning, Technical Report 1. Rome,pp.11-16.

FAO, 2003. Fishery country profile, Ethiopia. www.fao.org.

Finlayson. M., Davidson, N. C., Spires, A. G. and Stevenson, N. J., 1999. Global wetland inventory - current status and future priorities, Mar. Freshwater Res., 50: 717-727.

Hillman, J.C., 1993. Ethiopia: Compendium of Wildlife Conservation Information. NYZS - The Wildlife Conservation Society, International, New York Zoological Park, Bronx, NY and Ethiopian Wildlife Conservation Organization, Addis Ababa, (2):786pp

Hughes, R.H. and Hughes, J.S., 1992. A directory of African wetlands: World Conservation Union (IUCN), Gland (Switzerland); UNEP, Nairobi (Kenya); World Conservation Monitoring Centre, Cambridge (UK), pp.820831.

Illueca, J. and Rast, W., 1996. Freshwater Resources: precious, finite and irreplaceable. Our Planet 8 (3): 19-21.

Jos, T.A., Boudewijn, B., Dennis, F.W. and Roland, B., 2006. Wetlands and Natural Resource Management: Wetland Functioning in a Changing World Implications for Natural Resources Management, Springer-Verlag Berlin Heidelberg, Ecological Studies, 190: 80-85.

Legesse, T., 2007. The Dynamics of Wetland Ecosystems: A case study on hydrologic dynamics of the wetlands of Ilu Abba Bora Highlands, South-west Ethiopia. Thesis Presented to Obtain the Degree of Master in Human 
Ecology, Brussels,pp.30-35.

Legesse, T., 2008. The Roles of Wetlands in Food Security and Poverty Reduction in Ethiopia: Ethiopian Wetlands and Natural Resources Association, pp. 28-36.

Lemlem, S., 2003. Biodiversity potentials and threats to the southern Rift Valley lakes of Ethiopia. In Wetlands of Ethiopia, proceedings of a seminar on the resources and status of Ethiopia's wetlands, (eds.) Abebe and Geheb, K., IUCN ,pp. 31-34 .

Leykun, A., 2003. The Distribution And Status Of Ethiopian Wetlands: An Overview: IUCN,pp.12-17.

McCartney, M. P., Masiyandima, M. and Houghton-Carr,H. A., 2005. Working wetlands: Classifying wetland potential for agriculture. Colombo, Sri Lanka: International Water Management Institute (IWMI), pp. 31-38.

Mengistu, W., 2008. The role of Wetlands in Biodiversity Conservation and Management in Ethiopia: A case study of Berga Floodplain: Ethiopian Wildlife and Natural History Society (EWNHS),pp.72-86.

Nyman, J.A., 2011. Wetlands integrating Multidisciplinary concept: Ecological Function of wetland Lepage, A.B, (eds),Springer Science, Business Media B.V, pp.115-116.

Ramsar Bureau ,2004. The Ramsar Convention Manual: a Guide to the Convention on wetlands, $3^{\text {rd }}$ edition,pp.1012.

Ramsar Convention Manual, (2006). A Guide to the Convention on Wetlands (Ramsar, Iran, 1971) $4^{\text {th }}$ edition. Ramsar Convention Secretariat. pp. 5-15.

Shewaye, D., 2008. Wetlands and Management Aspects in Ethiopia: Situation Analysis: Ethio Wetlands and Natural Resources Association, pp. 14-16.

Silvius, M.J., Oneka, M. and Verhagen, A., 2000. Wetlands: Lifeline for People at Edge. Phys.Chem.Earth (B), Elsevier Science Ltd, 25(7-8):645-652.

Siraj, B., 2004. Wetlands of Oromia: Their conservation and contribution to food security and poverty reduction. Proceedings of the National Consultative workshop on the Ramsar Convention and Ethiopia, March 18-19, 2004, Addis Ababa Ethiopia. pp. 12-16.

Teferi, E., Uhlenbrook, S., Bewket, W., Wenninger, J. and Simane, B., 2010.The use of remote sensing to quantify wetland loss in the Choke Mountain range, Upper Blue Nile basin, Earth System Science, (14):2415-2428.

Tilahun, S., Edwards, S. 1996. Important Bird Areas of Ethiopia: A First Inventory. B. G. E. Tewolde (eds.). Ethiopian Wildlife and Natural History Society, Addis Ababa. 300pp.

UNEP/CBD, 2006. Biological Diversity Of Inland Water Ecosystems: conference of the parties to the convention on biological diversity eighth meeting, Curitiba, Brazil, 32pp.

WCED (World Commission of Environment and Development), 1987. Our Common Future. WCED. Oxford University Press. New York, U.S.A. 398pp.

Williams, M., 1990. Wetlands: A Threatened Landscape. UK, Institute of British Geographers, Oxford, pp.419421. 